\title{
Zero Emission Steam Technology: Clean Electric Power from Fossil Fuels
}

\author{
J. Ray Smith
}

July 31, 2001

U.S. Department of Energy

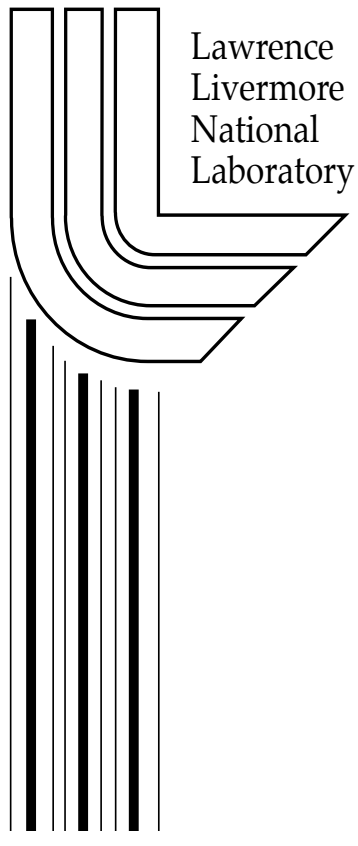




\section{DISCLAIMER}

This document was prepared as an account of work sponsored by an agency of the United States Government. Neither the United States Government nor the University of California nor any of their employees, makes any warranty, express or implied, or assumes any legal liability or responsibility for the accuracy, completeness, or usefulness of any information, apparatus, product, or process disclosed, or represents that its use would not infringe privately owned rights. Reference herein to any specific commercial product, process, or service by trade name, trademark, manufacturer, or otherwise, does not necessarily constitute or imply its endorsement, recommendation, or favoring by the United States Government or the University of California. The views and opinions of authors expressed herein do not necessarily state or reflect those of the United States Government or the University of California, and shall not be used for advertising or product endorsement purposes.

This work was performed under the auspices of the U. S. Department of Energy by the University of California, Lawrence Livermore National Laboratory under Contract No. W-7405-Eng-48.

This report has been reproduced directly from the best available copy.

Available to DOE and DOE contractors from the

Office of Scientific and Technical Information

P.O. Box 62, Oak Ridge, TN 37831

Prices available from (423) 576-8401

http: / / apollo.osti.gov/bridge/

Available to the public from the National Technical Information Service

U.S. Department of Commerce 5285 Port Royal Rd., Springfield, VA 22161 http:/ / www.ntis.gov/

OR

Lawrence Livermore National Laboratory Technical Information Department's Digital Library http:/ / www.llnl.gov/tid/Library.html 


\section{Zero Emission Steam Technology: Clean Electric Power from Fossil Fuels}

As demand for electricity grows, the United States needs practical technologies for generating electricity without causing environmental harm-such as the Zero Emission Steam Technology (ZEST) developed by Clean Energy Systems, Inc.

However, further research is required to reduce the scientific and economic risks before the U.S. electric power industry will embrace ZEST. Therefore, Clean Energy Systems, Inc., along with energy-generation stakeholders and in partnership with Lawrence Livermore National Laboratory, proposes to build a ZEST research facility for performing research.

\section{ZEST Offers Multiple Benefits}

The ZEST system has both economic and environmental benefits:

- Efficient, low-cost power generation.

- Ability to use a range of fossil fuels, including natural gas, coal syngas, and coalbed methane.

- No greenhouse gases or oxides of nitrogen emitted to the atmosphere.

- Geologic sequestration of the carbon dioxide produced.

- Enhanced oil recovery in mature fields, using the carbon dioxide produced.

Reducing U.S. dependence on imported energy resources is critical for the nation's economic and military security. ZEST power plants can help the United States reduce its energy dependence by making better use of extensive domestic energy resources, such as coal.

\section{How ZEST Works}

The ZEST combustion process is based on rocket engine technology. A ZEST plant will burn pure oxygen with a gaseous hydrocarbon fuel to produce power. The ZEST gas generator has independent temperature and pressure control, which allows modular upgrading of the turbine systems as new, more efficient steam-turbine technology becomes available. It is envisioned that the ZEST research facility would serve as a testing laboratory for new steam-turbine technology.

In its initial phase, ZEST is expected to operate at $35 \%$ efficiency, using commercially available steam turbines, while future phases of the ZEST system should approach $60 \%$ efficiency. Based on a fuel cost of $\$ 5$ per million Btu natural gas, ZEST will generate electricity for less than 5 cents per kilowatt-hour. ZEST is expected to surpass all other fossil fuel power generation technologies in efficiency and economy of operation when carbon-dioxide sequestration is included. 


\title{
The Need for a ZEST Research Facility
}

Building and operating a ZEST research facility is a necessary step toward commercializing this technology with high efficiency. The U.S. electric power industry typically requires tens of thousands of hours of operational data before investing in a major new technology. The scope of work and the multiyear research commitment required for proof-of-concept make the proposed project a good fit for a multidisciplinary technical organization such as a U.S. Department of Energy national laboratory.

\section{Why Build This Facility at Livermore?}

In addition to technical expertise, Lawrence Livermore National Laboratory (LLNL) provides a valuable combination of site and regional attributes, including close proximity to a mature oil field and a confined, nonpotable aquifer. Both types of geological formations offer excellent potential for long-term sequestration of carbon dioxide. This setting presents an opportunity to establish - as an integral component of ZEST - a U.S. geologic carbon sequestration field laboratory facility that explicitly integrates advanced modeling and field studies of carbon-dioxide injection for both enhanced oil recovery and pure environmental isolation.

LLNL's expertise in research areas critical to successful development of ZEST makes this national laboratory the logical host for such a facility. These critical areas include: cutting-edge oxygen separation techniques, thermal barrier coating development for high-temperature steam turbines, computational simulation of combustion processes and geologic carbon-dioxide sequestration, geophysical imaging and analysis, and enhanced oil production methodologies for seismically active basins.

Important regional attributes include strong San Francisco Bay Area support for clean energy and environmental technologies, ready access to two power grid feeds, a controllable nearby baseload, and a highly stressed local grid that will benefit from additional power.

\section{Estimated Cost and Schedule}

Based on a preliminary Bechtel costing study, the 10-megawatt ZEST research facility is estimated to cost $\$ 70$ million (including 35\% contingency) and will require two years to construct.

Contact: $\quad$ Ray Smith

\author{
Lawrence Livermore National Laboratory \\ P.O. Box 808, L-644 \\ Livermore, CA 94551 \\ Phone: (925) 422-5196 \\ Fax: (925) 423-7914 \\ Email: jrsmith@llnl.gov
}

UCRL-ID-144955

This work has been performed under the auspices of the U.S. Department of Energy by the University of California, Lawrence Livermore National Laboratory under Contract No. W-7405-Eng-48. 